\title{
The maintenance costs of marine natural capital: A case study from the initial assessment of the Marine Strategy Framework Directive in France
}

\author{
Harold Levrel ${ }^{a, *}$, Céline Jacob ${ }^{a}$, Denis Bailly ${ }^{b}$, Mahe Charles $^{d}$, Olivier Guyader ${ }^{a}$, \\ Schéhérazade Aoubid ${ }^{e}$, Adeline Bas $^{b}$, Alexia Cujus ${ }^{e}$, Marjolaine Frésard ${ }^{c}$, Sophie Girard ${ }^{a}$, Julien Hay ${ }^{c}$, \\ Yann Laurans ${ }^{\dagger}$, Jérôme Paillet ${ }^{d}$, José A. Pérez Agúndez ${ }^{a}$, Rémi Mongruel ${ }^{\mathrm{a}}$ \\ a IFREMER, UMR AMURE, Marine Economics Unit, Centre de Brest, Zl Pointe du Diable, 29280 Plouzané, \\ France \\ ${ }^{\mathrm{b}}$ Université de Brest, UMR AMURE, IFREMER, Centre de Brest, ZI Pointe du Diable, 29280 Plouzané, France \\ c Université de Brest, UMR AMURE, 29334 Quimper Cedex, France \\ d Marine Protected Area Agency, 16 Quai de la Douane CS 42932, 29229 Brest Cedex 2, 29200 Brest, France \\ e ECOWHAT, 99 Rue Duhesme, F-75018 Paris, France \\ ${ }^{\mathrm{f}}$ Institut du Développement Durable et des Relations Internationales, 41, rue du Four 75006 Paris, France
}

*: Corresponding author : Harold Levrel, email address : $\underline{\text { Harold.Levrel@ifremer.fr }}$

\begin{abstract}
:
There are two ways of assessing the costs of environmental degradation: as the costs associated with the loss of benefits resulting from the degradation of natural capital, and as the maintenance costs required to compensate for the actual or potential degradation of natural capital. The first of these methods is based on the Total Economic Value (TEV) of benefits forgone because of the depletion of ecosystem services delivered by marine biodiversity. The second method is based on the costs required to maintain a good state of marine biodiversity, one which makes it possible to deliver ecosystem services.
\end{abstract}

This paper gives an illustration of this second approach. It details how these maintenance costs have been calculated in the initial assessment of the Marine Strategy Framework Directive (MSFD) in France. It addresses nine problem areas - corresponding to nine sources of environmental degradation - from non-native invasive species to oil spills. It gives a total figure for these degradation costs (around 2 billion Euros). The results are compared with those of other Member States who have taken similar approaches in the context of the MSFD. One key conclusion is that it is not really possible to make meaningful comparisons at this stage, since the methods of data collection and the nature of the costs are very different. The need to develop such assessments in a standardised way is noted.

\section{Highlights}

The MSFD requires an assessment of the degradation costs of the marine environment. In France, these costs have been assessed from the maintenance costs method. The cost of environmental degradation in French waters is 2.054 billion Euros. This result is balanced with those of other Member State.

Keywords: Maintenance cost ; Marine ecosystems ; Marine Strategy Framework Directive ; Economic analysis 


\section{Introduction}

This paper discusses the assessment of the cost of environmental degradation, in the policy context of the Marine Strategy Framework Directive (MSFD). The MSFD represents the environmental component of the European integrated marine approach (2008/56/EC) and establishes a legislative framework for community action in the area of marine environmental policy. The ultimate aim is to design a programme of environmental measures to achieve a good environmental status (GES) by 2020. The MSFD is founded on an initial assessment of the current environmental status of national marine waters and a socio-economic analysis of human activities in these waters (carried out in 2012). The initial socio-economic assessment includes an analysis of the costs of degradation of the marine environment.

There are two ways of assessing the costs of environmental degradation [1]: as the costs associated with the loss of benefits resulting from the degradation of natural capital [2], [3], and as the maintenance costs required to compensate for the actual or potential degradation of natural capital [4], [5]. The first method for assessing the costs of environmental degradation is based on the Total Economic Value (TEV) of benefits forgone because of the depletion of ecosystem services delivered by marine biodiversity. The second method is based on the costs required to maintain a good state of marine biodiversity which makes it possible to deliver ecosystem services.

The expert group of economists charged with assessing the cost of degradation of the marine environment in France recognised the limits and difficulties of capturing the TEV of the environmental benefits discussed in the literature (see the Method section), and decided to use the maintenance costs method.

This paper presents the results of this assessment, and attempts to describe the challenges, strengths and limits of the maintenance cost assessment method.

The paper is organised as follows: the method and the data used to assess the costs of degradation in the French case study are described and discussed; next, the results of the assessment are detailed; finally, the results are discussed and compared with those of other Member States who have taken similar approaches in the context of the MFSD. In conclusion, the strengths, limits and prospects of these types of assessment are discussed.

\section{Materials and method}

\subsection{Context}

In France, the economic analysis of the costs of degradation has been assigned to an expert group of economists, specialists in marine economics who belong to the Centre for the Law and Economics of the Sea (UMR AMURE ${ }^{1}$ ), working closely with the Ministry of Ecology, Sustainable Development and Energy ${ }^{2}$ and with the Marine Protected Area Agency. ${ }^{3}$ To carry out the work two full-time agents were recruited, and three part-time external consultants were involved in the assessment process. ${ }^{4}$ It was decided, in accordance with the MSFD, that this analysis had to be based on available data and carried out on a sub-regional scale. The analysis took four marine sub-regions into account: the Occidental Mediterranean Sea (OMS), the Channel-North Sea (CNS), the Bay of Biscay (BOB) and the Celtic Sea (CS) (Figure 1). Contributions for the Celtic Sea have sometimes been included in Channel-North

\footnotetext{
${ }^{1} \mathrm{http}: / /$ www.umr-amure.fr/index2.php

${ }^{2} \mathrm{http}: / /$ www.developpement-durable.gouv.fr/

${ }^{3} \mathrm{http}: / /$ www.aires-marines.com/

${ }^{4}$ The experts, consultants, and agents recruited for this task are listed as co-authors.
} 
Sea, or not included if data were not available. This analysis did not take French Overseas Territories into account.

\section{FIGURE 1}

\subsection{Economic assessment methods}

As mentioned in the Introduction, there are two ways to assess the cost of environmental degradation: through the loss of benefits or through the cost of compensating for this degradation.

From the point of view of standard economic theory the first approach is more robust, since it is in accordance with the welfare optimisation analysis [6]. However, there are at least six major practical issues which have to be addressed when considering monetary valuation of non-use values, indirect use values, and even simple non-market use values such as recreational activities [2], [7], [8], [9]: the lack of data on interactions between biological entities, ecological functions, ecosystem services production, and changes in well-being [10], [11], [12], [13]; the high level of uncertainty regarding some of the values based on support services or cultural services [14], [15]; the controversies around the benefit-transfer method for extrapolating local values to a regional or national scale [16], [17], [1]; the controversies around the stated preferences analysis for capturing non-use, indirect use, and non-market use values [18], [19], [20]; ethical issues regarding the commensurability and monetisation of nature [21], [22]; and the limits of the TEV as a source of relevant information when the analysis is used in a policy framework in which certain strong sustainability goals are fixed [23], [24].

Recognising these limits, Pearce [8] has proposed paying attention to the real costs borne by society to provision and maintain ecosystem services - that is, the costs of conservation policies. Bartelmus [4] also suggests paying attention to the maintenance costs of a given environmental state. ${ }^{5}$

The maintenance cost assessment has, until now, mainly been used in specific environmental policies for the calculation of the environmental restoration costs associated with environmental damage following a pollution event [25], [26], [27]. In this context, the assessment is carried out to determine how much the polluters have to pay to restore what they have damaged and to reach a "no net loss" goal of ecosystem services, acting in accordance with a strong sustainability principle [26], [28]. Concretely, in the MSFD the maintenance costs can be understood as the real expenditures that a socio-economic system needs in order to maintain the level of natural capital required to deliver a certain level of ecosystem services.

This method does not take the economic welfare theory into account but draws on a basic accountability theory. Maintenance costs can therefore be disproportionate with respect to the measurable benefits resulting from the expenditures required to maintain the level of natural capital [3] (Table 1). This is clearly one of the main limits of this method; but it is also one of the strengths of the maintenance cost approach.

\section{TABLE 1}

\footnotetext{
5 "Maintenance cost is applied to environmental degradation. The SEEA reviews maintenance costing critically as the hypothetical cost of avoiding pollution or restoring the polluted environment ([5], ch.10D). Maintenance cost can be seen, however, as the weights for actual environmental impacts, according to societyes obligation and capacity for dealing with environmental concerns ${ }^{\text {ee" }}$ ([4], p.145); "Such costing is indeed more practical than the assessment of elusive damage effects from environmental impacts" ([4], p.1851).
} 
Thus, the maintenance costs assessment makes sense only within a policy framework in which some environmental standards have been adopted, reflecting the level of natural capital that a society agrees to maintain through a specific level of investment. This policy framework is a product of compromise over the formulation of the environmental problem, the norms and rules which are necessary to tackle this issue, and the effort (measured in terms of changes in use and/or restoration programmes) required to achieve them. The MSFD includes a clear environmental normative reference (the GES), reflecting a strong sustainability goal, which will be the product of a number of negotiation processes and political trade-offs.

In this context, it is inappropriate to provide a TEV resulting from individual aggregated preferences, ${ }^{6}$ since that would be based on a different normative principle from the GES, namely the maximum of welfare. But it might seem meaningful to know the current maintenance costs devoted to marine environmental ecosystem management, considering the gap between the present situation and the GES goal. Indeed, to achieve the GES will require improving and complementing existing marine environmental management measures, which will generate additional costs. From this perspective, the maintenance cost approach will also provide the basis for a future cost-effectiveness analysis of the complex management system which will result from the Program of Measures recommended by the MSFD. It is for these reasons, in addition to those mentioned in the introduction, that the team of experts believed that this approach was the best to use for assessing the costs of environmental degradation.

The costs of environmental degradation discussed in this paper are the real expenditures devoted to conservation of the marine environment in $2010 .^{7}$ However, even though the problems have been defined on the basis of the GES descriptors, it has not been possible to use the GES standards to calculate initial maintenance costs. In addition, since the GES standards are not supposed to be complied with before 2020, these standards are not suited to calculating maintenance costs in 2010. The team of French economists thus adopted the current legal norms, specific to each degradation problem area, as the best substitute (Table 2).

The maintenance costs were then divided into three categories (Figure 2).

- Costs of monitoring and information: aimed at improving information and coordination levels relative to conservation of the marine environment

- Costs of preventing environmental degradation: costs of specific investment in preventing and avoiding environmental impact

- Costs of environmental restoration and remediation: costs of environmental restoration and remediation after destruction or an ecological accident.

\section{FIGURE 2}

\subsection{Data}

Data on the environmental costs was collected in 2011, with 2010 as the year of reference for our assessment.

\footnotetext{
${ }^{6}$ Assuming that it is impossible to set an aggregation rule that would make it possible to sum individual preferences within a TEV in a way that would be in accordance with the norms that society as a whole agrees to be essential, as noted long ago by Kenneth Arrow (1950), the maintenance cost assessment seems to be more suited to the MSFD in which some normative environmental goals have already been adopted.

${ }^{7}$ This was the last year of available data at the time the study was carried out.
} 
Cost assessment has been broken out into nine "degradation problem areas": Marine litter;

\section{TABLE 3}

\section{TABLE 4}

The survey was conducted using the following questions:

- Is your organisation involved in one of the following types of activity: activities related to monitoring or information; measures for sustainable management, control, and enforcement; compensatory measures or restoration? (this question was modified depending on the remit of the organisation)

- Can you give some examples of activities? (this question was modified depending on the remit of the organisation)

- Can you give details of the budget allocated to each activity and the full-time staff equivalent devoted to each one?

- Do you have a financial statement which breaks out the different activities pursued?

- Does the budget allocated to each activity change from one year to the next?

Unfortunately, data about the costs associated with some of the problem areas are not available on a large scale, or have turned out to be incomplete or of very poor quality. This is why the costs related to two of the problem areas, invasive species and marine litter, are not detailed in this paper. However, the lack of accurate data does not mean that the costs associated with these two problems are insignificant.

When data for 2010 were not available or when using data from only one year did not make sense (due to high variability of the costs from one year to the next, such as in the case of oil spills), an inter-annual average was calculated.

\section{Results}


The total expenditure devoted to maintaining the current ecological status of marine waters for France was more than 2,054 million euros a year in 2010 (Table 5). A significant proportion of these costs (1,247 million euros) was related to preventing environmental degradation by microbial pathogens, and took the form of enforcement of water quality standards ( $99 \%$ of the cost was expended on wastewater treatment). These expenditures have as their primary purpose the protection of the health of human populations, and the benefits for the natural environment are indirect. This is the reason why the costs are the highest. The perception of the risks associated with water pollution is greater when human health may be impacted than when only biodiversity is affected. The second highest was the chemical compounds category, with costs associated with prevention of chemical pollution amounting to 347 million euros ( $81 \%$ of the cost was expended on industrial wastewater treatment). Here again, the goal is protection of human health, which explains the size of this expenditure. Next come the costs associated with loss of biodiversity and decrease of fish stocks, 148 and 133 million euros respectively. The high costs associated with fishing are due to the increasing erosion of fish stocks and the need for more sustainable management of these stocks (67\% of costs). The costs linked to biodiversity loss are mainly related to monitoring and reporting (52\% of costs), which indicate substantial interest in these issues and a serious lack of scientific data. Finally there are three problems for which the costs of environmental degradation are much lower: eutrophication (47.4 million euros), oil pollution (47.3 million euros), and degradation of exploited resources related to aquaculture (30 million euros). The costs of preventing environmental degradation caused by oil spills and illegal discharges come last, due to the fact that anticipating and preventing damage associated with accidental marine pollution is difficult, and also that political action to prevent such damage still seems inadequate.

\section{TABLE 5}

\subsection{Costs broken out by type and marine sub-region}

The costs of preventing environmental degradation are by far the highest, at 1.7 billion euros (Table 5). This is mainly due to wastewater treatment for microbial pathogens and chemical compounds (accounting for $89 \%$ of these costs). Of the other five problem areas, three (biodiversity loss, oil spills and illegal discharges, and erosion of exploited resources for aquaculture) involve costs of monitoring and information which are higher than the costs of preventing environmental degradation. The costs of environmental restoration and remediation are always the lowest, except for two problem areas (oil spills and illegal discharges, eutrophication) in which they come second; the costs associated with these two areas are related to clean-up of oil spills and green algae. Another point brought out by the analysis is that the erosion of biodiversity and oil pollution and illegal discharges are the two main contributors to the costs of environmental restoration and remediation.

The relative weight of the different types of cost is variable across the marine sub-regions. The distribution of the costs of monitoring and information is more or less the same in all the marine sub-regions (Figure 3), except for aquaculture, because this activity is mainly conducted in the Bay of Biscay where most of the shellfish farming businesses are located.

\section{FIGURE 3}


The distribution of the costs of preventing environmental degradation is highly variable (Figure 4), chiefly because the Occidental Mediterranean Sea benefits from a higher level of expenditure for the prevention of marine environmental degradation than the other two subregions. The high demographic density (sources of pollution and urbanisation), with $47 \%$ of the coastal population of France located in the Mediterranean sub-region, explains why costs associated with wastewater treatment for microbial pathogens and with land acquisition for biodiversity protection are higher. Moreover, the cultural-symbolic significance of the Mediterranean ecosystem and the level of pressure exerted on it create greater political interest in biodiversity protection in this region.

Among other differences, the cost of prevention related to managing chemical compounds is significantly higher in the Channel-North Sea, where there is a long history of industrial activity. The cost of eutrophication is zero in the Occidental Mediterranean Sea because the principal cause of eutrophication in France is organic nitrates, mainly resulting from intensive livestock breeding located mostly in Brittany (2/3 of this in the Bay of Biscay sub-region and $1 / 3$ in the Channel-North Sea sub-region); the only areas affected by eutrophication in the Mediterranean are lagoons, which are not taken into account in the MSDF. The greater cost of preventing environmental degradation relative to aquaculture in the Bay of Biscay is in line with the importance of aquaculture in the area.

\section{FIGURE 4}

The costs of environmental restoration and remediation are significantly lower than the two other types of cost, and mainly affect the Channel-North Sea sub-region (Figure 5). Three factors are relevant here. Compensation for biodiversity losses comes from harbour infrastructure development, granulate extraction, and compensation for environmental damage from recent oil spills in this area. It is necessary to collect and treat green algae on beaches where eutrophication is a source of green tides. Oil spills have also occurred in the Bay of Biscay.

Compensation costs for biodiversity loss are legally mandated (see Table 5). These costs are very substantial in the Channel-North Sea and in the Bay of Biscay, since there has been some project development (especially new harbours). In the Occidental Mediterranean Sea, the costs of restoration are mainly due to voluntary efforts conducted in marine protected areas to restore degraded ecosystems.

\section{FIGURE 5}

\section{Discussion}

The main question discussed in this paper, as noted in the Introduction, is the feasibility and robustness of the maintenance cost assessment method for evaluating environmental degradation costs. The literature on the maintenance costs of marine ecosystems seems limited to the costs of establishing and managing marine protected areas [29], [30], [31]. In the present study, we have attempted to produce an integrated assessment of maintenance costs for all the environmental components of French marine ecosystems. In order to take the interpretation of the results farther, they have to be compared with the assessments and studies carried out by other Member States; however, the limits of such a comparison also need to be recognised. 


\subsection{Comparisons with other national studies}

First, it is interesting to compare our results with those of other Member States who have taken similar approaches in the context of the MFSD, especially the Netherlands and Spain. In the Netherlands, total expenditure devoted to the maintenance of desirable environmental conditions amounts to 1.58 billion euros a year [32]. Our estimated figures are fairly close to this, but the French coastline is seven times as long as that of the Netherlands. In Spain, total expenditure for the maintenance of marine natural capital was around 1.53 billion euros in 2010, divided into seven problem areas [33]. Even if the problem areas are more or less similar to the French ones, there are many differences in the way the Member States have broken out the expenditures to be taken into account to calculate the cost of degradation. The differences between these results are difficult to interpret at this stage, since the methods were not harmonised before the data were collected.

However, despite the heterogeneous calculation methods, these results can be compared in some ways. For instance, the cost of water treatment in the river catchments represents the lion ${ }^{\text {ee }}$ s share of expenditures in each case $(73 \%$ in France, $90 \%$ in the Netherlands, $38 \%$ in Spain). As noted above, this may be due to the fact that it is necessary to protect human health.

\subsection{Comparisons of cost and effectiveness}

This assessment should serve to define environmental goals, taking social and economic considerations into account. This in turn will feed into cost/benefit and cost/effectiveness analyses of measures to be defined by 2015 and will help identify disproportionate costs.

In subsequent years, our results ought to help in monitoring the additional environmental degradation costs that will result from the implementation of new legal norms (GES) associated with the MSFD. The programme of measures designed to reach the GES will indeed add new costs for public and private stakeholders. The key question is whether the efforts to reach the GES will be cost-effective. Answering this will require assessing environmental degradation costs again in 2015 and 2020, in order to monitor increases in costs and the associated GES descriptors.

One limitation of this assessment is that these costs are meaningful only if they are balanced against the effectiveness of the conservation activity. For this reason, an additional indicator could be adopted to assess the level of effectiveness of environmental policies. This indicator would tell us whether the legal norm has been attained. Even if it has not, some impacts on society are still expected to be observable: these may be called "residual impacts". Nonmonetary indicators can also be used, such as numbers of days when shellfish farming is prohibited due to bacterial pollution, time spent removing litter from fishing-nets, number of oil-coated birds, and so on.

\subsection{Limits of the maintenance cost method and recommendations}

All these comparisons highlight the lack of standardisation and homogenisation of maintenance cost assessment methods, in contrast to conventional monetary economic valuations which have been discussed for a long time in the literature and are more clearly defined.

At this stage, there is no point in making any comparisons, given the lack of common methods for collecting data. In addition, it seems that the reported level of these costs is deeply influenced by the sampling efforts: the more actively you look for expenditures, the more the costs of maintenance are increased. 
It is also important to note that this method is really time-consuming. The data collection took almost one year and required one full-time person plus one available expert for each of the "problem areas", in order to be sure that the costs about which information was collected are clearly related to the maintenance of the natural capital being assessed.

To improve the level of the quality of such assessments, it is crucial to develop some standards regarding

- A data collection framework or guidelines which would make it possible to: (1) define some categories of cost, as proposed in this paper; (2) target the organisations where collecting information on these costs is necessary; and (3) spell out how the interviews with the organisation representatives must be conducted, what sampling frame and extrapolation variables can be used if it is not possible to gather exhaustive data, and what types of cost are eligible (or not) for the assessment.

- An accounting system framework which would make it possible to: (1) link up with the national accountability system and companiese accountability systems; (2) organise the data collection; and (3) make comparisons using macro-economic and micro-economic indicators as well as ecological indicators from which effectiveness analysis could be carried out.

The only source of such standards are the United Nations systems of economic and environmental accounting [4]. It seems important to make the link between these accounting systems and this type of evaluation more explicit. It would also be useful to standardise the typology of management interventions (observation, prevention, and maintenance or restoration) that Member States will implement in their MSFD Programme of Measures in order to facilitate ex-ante and ex-post assessments of these Programmes, as well as comparisons across Member States.

\section{Acknowledgements}

We would like to thank Mateo Cordier and the anonymous reviewers for all the comments and corrections on this paper, which have helped greatly to improve it. We also wish to thank all the people who were interviewed for our work.

\section{References}

[1] The economics of ecosystems and biodiversity. Mainstreaming the economics of nature: A synthesis of the approach, conclusions and recommendations of TEEB. Final Report. European Commission; 2010.

http://www.teebweb.org/Portals/25/TEEB\%20Synthesis/TEEB_SynthReport_09_2010_onlin e.pdf.

[2] Barbier EB, Baumgärtner S, Chopra K, Costello C, Duraiappah A, Hassan R, Kinzig A, Lehmann M, Pascual U, Polasky S, Perrings C. The valuation of ecosystem services. In: Naeem S, Bunker DE, Hector A, Loreau M, Perrings C (eds). Biodiversity, Ecosystem Functioning, and Human Well Being. Oxford and New York: Oxford University Press 2009; 248-262.

[3] Environmental Protection Agency. Valuing the protection of ecological systems and services. Report of the EPA Science Advisory Board. Washington DC: 2009. 
[4] Bartelmus P. The cost of natural capital consumption: Accounting for a sustainable world economy. Ecological Economics 2009; 68:1850-1857.

[5] United Nations, European Commission, International Monetary Fund, Organisation of Economic Cooperation and Development, World Bank. Integrated environmental and economic accounting 2003. New York: United Nations; 2003.

http://unstats.un.org/unsd/envAccounting/seea.htm, 572 pp.

[6] Mäler KG, Aniyar S, Jansson $\AA$. Accounting for ecosystem services as a way to understand the requirements for sustainable development. Proceedings of the National Academy of Sciences 2008; 105:9501-9506.

[7] Heal G. Nature and the marketplace: Capturing the value of ecosystem services. Washington DC: Island Press; 2000.

[8] Pearce D. Do we really care about biodiversity? Environmental and Resource Economics 2007; 37:313-333.

[9] Wallace K. Ecosystem services: Multiple classifications or confusion? Biological Conservation 2008; 141:353-354.

[10] Costanza R, Fisher B, Mulder K, Liu S, Christopher T. Biodiversity and ecosystem services: A multi-scale empirical study of the relationship between species richness and net primary production. Ecological Economics 2007; 61:478-491.

[11] Naeem S. Biodiversity, ecosystem functioning, and human wellbeing: An ecological and economic perspective. Oxford and New York: Oxford University Press; 2009.

[12] Carpenter SR, DeFries R, Dietz T, Mooney HA, Polasky S, Reid W, Scholes RJ. Millennium Ecosystem Assessment: Research needs. Science 2006; 314:257-258.

[13] Carpenter SR, Mooney HA, Agard J, Capistrano D, DeFries R, Díaz S, Dietz T, Duraiappah AK, Oteng-Yeboah A, Pereira HM, Perrings C, Reid WV, Sarukhan J, Scholes RJ, Whyte A. Science for managing ecosystem services: Beyond the Millennium Ecosystem Assessment. Proceedings of the National Academy of Sciences 2009; 106(5):1305-1312.

[14] Ludwig D. Limitations of Economic Valuation of Ecosystems. Ecosystems 2000; 3:3135 .

[15] Toman M. Why not to calculate the value of the world secosystem services and natural capital. Ecological Economics 1998; 25:57-60.

[16] Spash CL, Vatn A. Transferring environmental value estimates: Issues and alternatives. Ecological Economics 2006; 60:379-388.

[17] Braat L, ten Brink P. The cost of policy inaction (COPI) - The case of not meeting the 2010 Biodiversity Target. Final Report. European Commission; 2008.

[18] Kahneman D, Knetsch JL, Thaler RH. Experimental tests of the endowment effect and the Coase theorem. Journal of Political Economy 1990; 98:1325-1348. 
[19] Kahneman D, Ritov I. Determinants of stated willingness to pay for public goods: A study in the headline method. Journal of Risk and Uncertainty 1994; 9:5-37.

[20] Horowitz J, McConnell KE. Willingness to accept, willingness to pay, and the income effect. Journal of Economic Behavior and Organization 2002; 51(4):537-545.

[21] Espeland WN, Stevens ML. Commensuration as a social process. Annual Review of Sociology $1998 ; 24: 13-343$.

[22] Rutherford MB, Knetsch JL, Brown TC. Assessing environmental losses: Judgments of importance and damage schedules. Harvard Environmental Law Review 1998; 22:51-101.

[23] Ekins P, Simon S, Deutsch L, Folke C, De Groot R. A framework for the practical application of the concepts of critical natural capital and strong sustainability. Ecological Economics 2003; 44:165-185.

[24] Bithas K. Sustainability and externalities: Is the internalization of externalities a sufficient condition for sustainability? Ecological Economics 2011; 70:1703-1706.

[25] Dunford RW, Ginn TC, Desvousges WH. The use of habitat equivalency analysis in natural resource damage assessments. Ecological Economics 2004; 48(1):49-70.

[26] Roach B, Wade WW. Policy evaluation of natural resource injuries using habitat equivalency analysis. Ecological Economics 2006; 58:421-433.

[27] Zafonte M, Hampton S. Exploring welfare implications of resource equivalency analysis in natural resource damage assessments. Ecological Economics 2007; 61:134-145.

[28] Vaissière AC, Levrel H, Hily C, Le Guyader D. Selecting ecological indicators to compare maintenance costs related to the compensation of damaged ecosystem services. Ecological Indicators 2013; 29:255-269.

[29] Balmford A, Gravestock P, Hockley N, McClean CJ, Roberts CM. The worldwide costs of marine protected areas. Proc. Natl. Acad. Sci. U.S.A. 2004; 101(26): 9694-9697.

[30] Cullis-Suzuki S, Pauly D. Marine protected area costs as "beneficial" fisheries subsidies: A global evaluation. Coastal Management, 2010; 38(2): 113-121.

[31] McCrea-Strub A, Zeller D, Sumaila UR, Nelson J, Balmford A, Pauly D. Understanding the cost of establishing marine protected areas. Marine Policy 2011; 35(1): 1-9.

[32] Walker AN, Strietman WJ, Oostenbrugge JAE. The current cost of avoiding degradation of the Dutch North Sea environment. LEI Memorandum 11-009; 2011.

[33] Ministerio de medio ambiente y medio rural y marino. Marine Strategy Framework Directive economic and social analysis. Communication at the Subregional Coordination Meeting: Bay of Biscay and Iberian Coast (PT/SP/FR); 23 March 2012. 
Figure 1: Map of the four marine sub-regions

Figure 2: The different types of cost of degradation of the marine environment

Figure 3: Distribution of monitoring and information costs for each marine sub-region

Figure 4: Distribution of the costs of preventing environmental degradation for each marine sub-region

Figure 5: Distribution of the costs of environmental restoration and remediation for each marine sub-region 


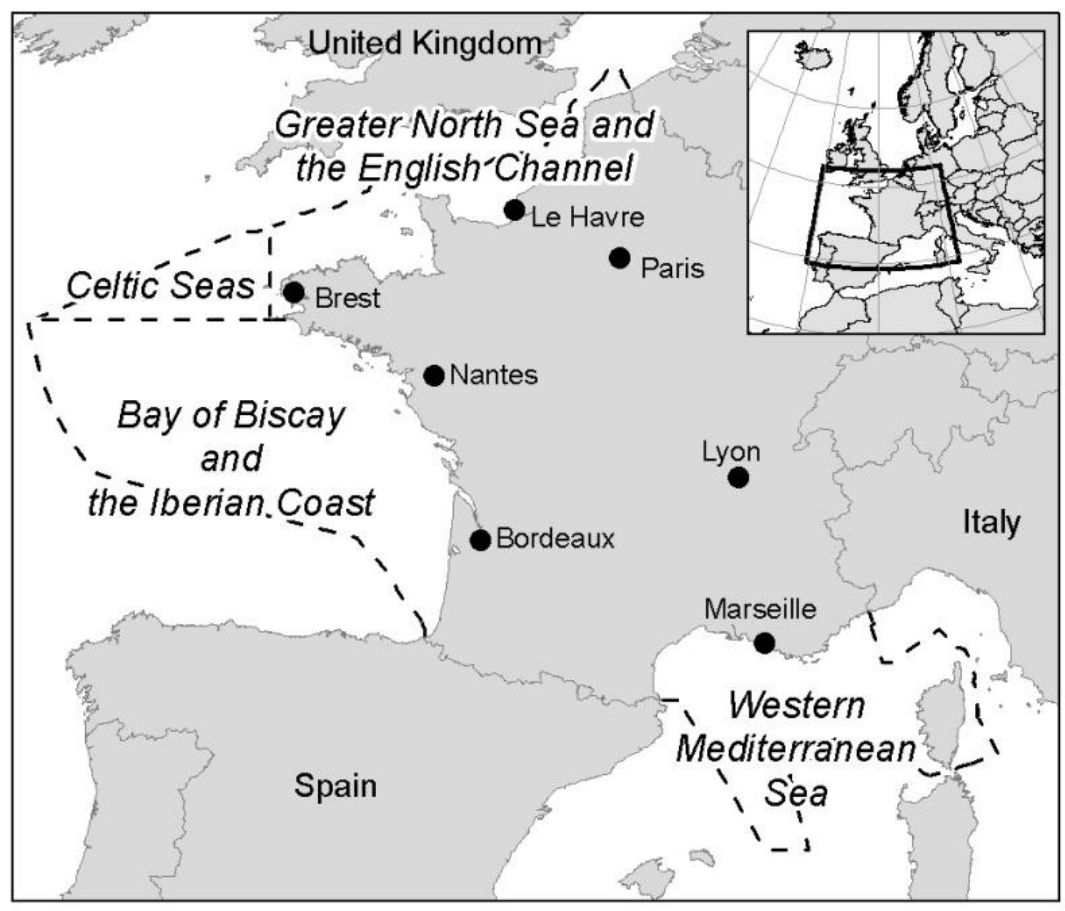




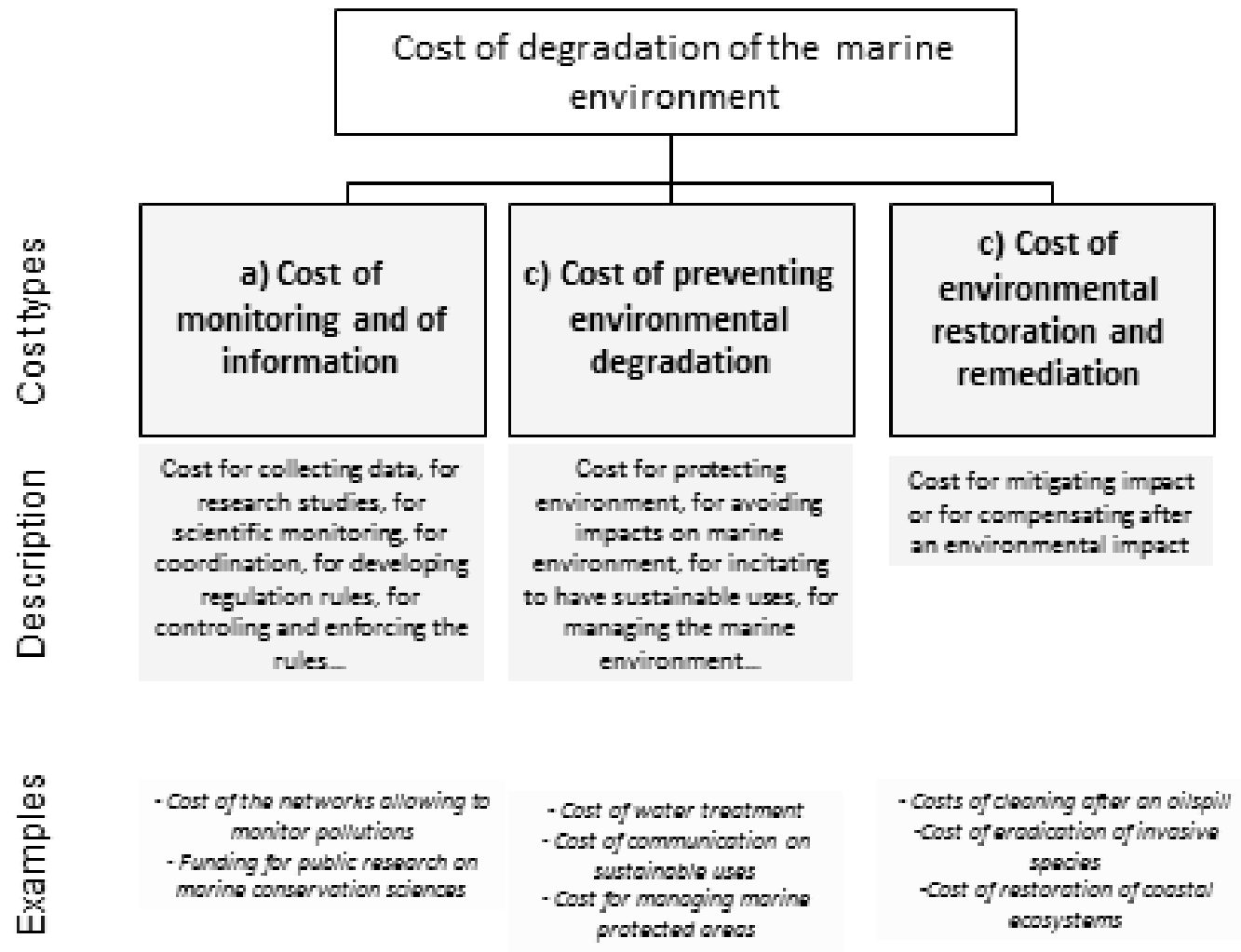




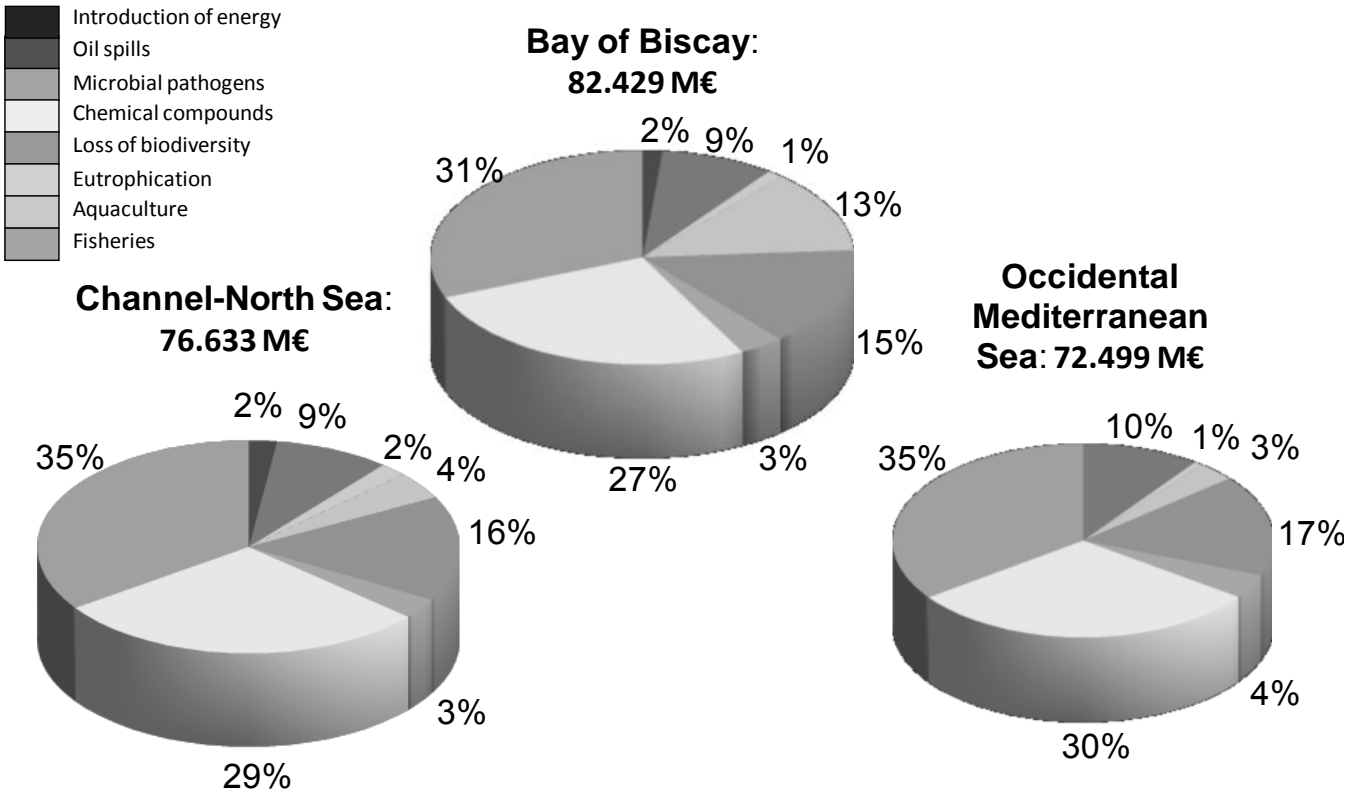

ay of Biscay:

Mediterranean

ea: $72.499 \mathrm{MC}$ 


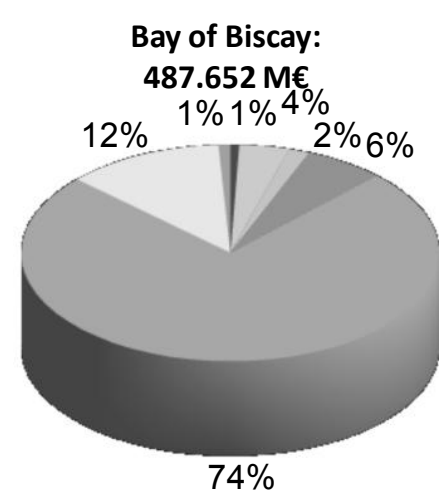

Occidental

Mediterranean Sea:

726.957 M€

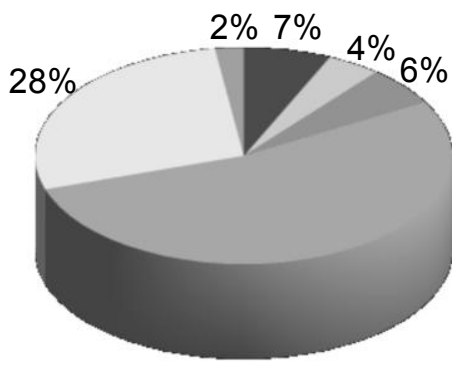

$53 \%$

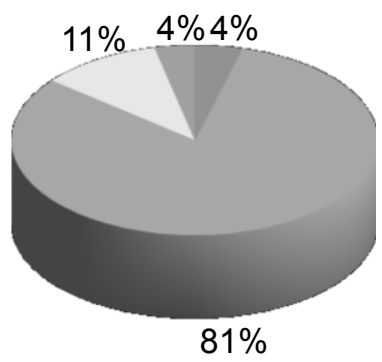



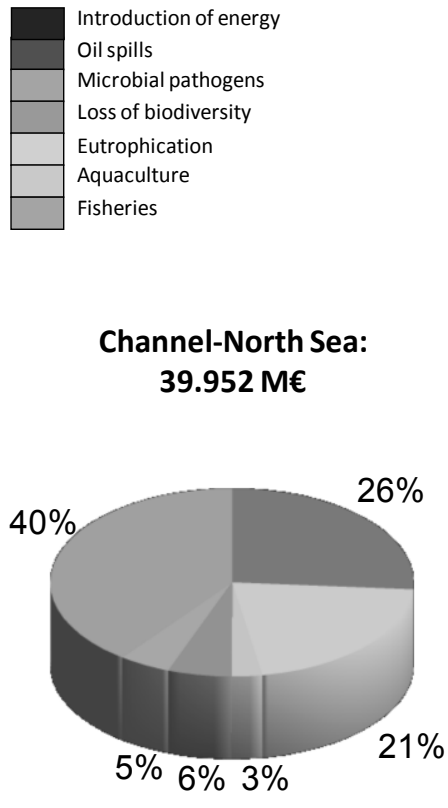

Bay of Biscay:

22.172 M€

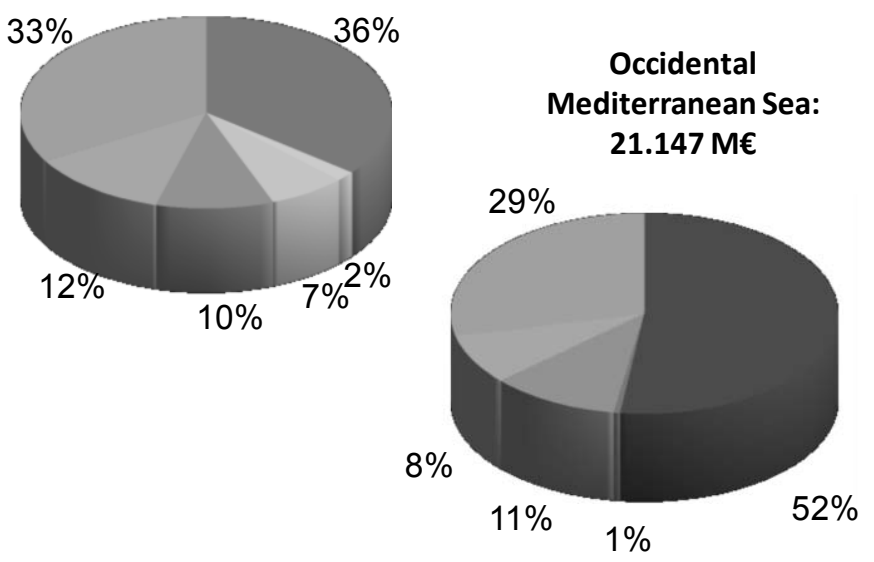


Table 1: Differences between the two ways of assessing the costs of environmental degradation

\begin{tabular}{|c|c|c|}
\hline & $\begin{array}{l}\text { Cost of maintaining the flow of } \\
\text { ecosystem services delivered by marine } \\
\text { biodiversity }\end{array}$ & $\begin{array}{l}\text { Total economic value of benefits } \\
\text { forgone because of the depletion of } \\
\text { marine biodiversity }\end{array}$ \\
\hline Rationale & $\begin{array}{l}\text { Investment required for restoring or } \\
\text { maintaining natural capital }\end{array}$ & $\begin{array}{l}\text { Monetary value associated with loss of } \\
\text { well-being resulting from the depletion of } \\
\text { ecosystem services }\end{array}$ \\
\hline Field of application & $\begin{array}{l}\text { Law regarding environmental } \\
\text { responsibility and environmental impact } \\
\text { assessment }\end{array}$ & $\begin{array}{l}\text { Financial analysis for project } \\
\text { management }\end{array}$ \\
\hline Cost assessment & Accounting costs & Economic costs \\
\hline Target & $\begin{array}{l}\text { Natural capital primarily, and indirectly } \\
\text { the well-being of the human population } \\
\text { benefiting from it }\end{array}$ & $\begin{array}{l}\text { Well-being of the population, including } \\
\text { positive and negative externalities }\end{array}$ \\
\hline Economic scale & Macro-economic (the socio-ecosystem) & Micro-economic (individual values) \\
\hline $\begin{array}{l}\text { Main limit of the } \\
\text { method }\end{array}$ & $\begin{array}{l}\text { This method does not take economic } \\
\text { welfare theory into account. Maintenance } \\
\text { costs can be disproportionate relative to } \\
\text { the benefit provided by the investment in } \\
\text { natural capital (EPA, 2009). }\end{array}$ & $\begin{array}{l}\text { Cost-benefit analysis does not say } \\
\text { anything about ecological sustainability. } \\
\text { The internalization of the externalities } \\
\text { can lead to major loss of biodiversity and } \\
\text { threaten social-ecological resilience } \\
\text { (Bithas, 2011) }\end{array}$ \\
\hline Unit of equivalency & $\begin{array}{l}\text { Biophysical units (habitat, species, } \\
\text { ecosystem services) }\end{array}$ & Value units (utility, price, well-being) \\
\hline Capital theory & Critical natural capital (Ekins, 2003) & $\begin{array}{l}\text { Genuine saving (Atkinson and Pearce, } \\
\text { 1993) }\end{array}$ \\
\hline $\begin{array}{l}\text { Large-scale assessment } \\
\text { method }\end{array}$ & Costs transfer & Benefits transfer (Brouwer, 2000) \\
\hline Level of sustainability & $\begin{array}{l}\text { Strong to medium: the natural capital loss } \\
\text { cannot be compensated for (replaced) by } \\
\text { anything but natural capital. However, the } \\
\text { level of compensation strongly depends on } \\
\text { the indicator of biophysical equivalency } \\
\text { used (habitat, species, etc.) }\end{array}$ & $\begin{array}{l}\text { Weak to medium: the natural capital loss } \\
\text { can be compensated for (replaced by) } \\
\text { human or manufactured capital. } \\
\text { However, it is possible to take into } \\
\text { account some thresholds which limit the } \\
\text { degree of substitutability }\end{array}$ \\
\hline
\end{tabular}


Table 2: Problem areas, links with MSFD, and current legal standards used to assess maintenance costs

\begin{tabular}{|c|c|c|}
\hline Problem areas & $\begin{array}{l}\text { GES descriptors, pressures, and } \\
\text { impacts in the MSFD included in the } \\
\text { analysis }\end{array}$ & Current legal framework \\
\hline Marine litter & descriptor 10 "marine litter" & 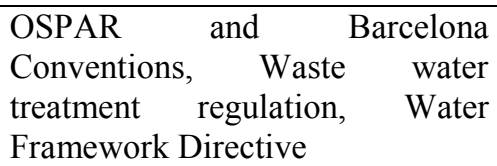 \\
\hline Chemical compounds & $\begin{array}{l}\text { descriptors } 8 \text { "contaminants and } \\
\text { pollution, ecological effects" and } 9 \\
\text { "contaminants in food" }\end{array}$ & $\begin{array}{l}\text { REACH Directive, Waste water } \\
\text { treatment regulation, Water } \\
\text { Framework Directive, Bathing } \\
\text { water regulation }\end{array}$ \\
\hline Microbial pathogens & $\begin{array}{l}\text { pressure-impact "introduction of } \\
\text { microbial pathogens" }\end{array}$ & $\begin{array}{l}\text { Waste water treatment regulation, } \\
\text { Water Framework Directive, } \\
\text { Bathing water regulation, } \\
\text { Regulation on animal products for } \\
\text { human consumption (Food law) }\end{array}$ \\
\hline Oil spills and illegal discharges & $\begin{array}{l}\text { descriptors } 8 \text { "contaminants and } \\
\text { pollution, ecological effects" and } 9 \\
\text { "contaminants in food" }\end{array}$ & $\begin{array}{l}\text { MARPOL, FIPOL, OSPAR and } \\
\text { Barcelona Conventions }\end{array}$ \\
\hline Eutrophication & descriptor 5 "eutrophication" & Nitrate Directive \\
\hline Non-native invasive species & descriptor 2 "non-native species" & $\begin{array}{l}\text { Ramsar, CITES, Berne, Bonn, } \\
\text { Biodiversity, Barcelona, OMI } \\
\text { Conventions }\end{array}$ \\
\hline $\begin{array}{l}\text { Biological degradation of natural } \\
\text { resources exploited (split into } 2 \\
\text { sub-problems, aquaculture and } \\
\text { fisheries) }\end{array}$ & $\begin{array}{l}\text { descriptor } 3 \text { "status of species } \\
\text { exploited" }\end{array}$ & $\begin{array}{l}\text { European common fisheries } \\
\text { policy }\end{array}$ \\
\hline $\begin{array}{l}\text { Loss of biodiversity, trophic } \\
\text { changes, loss of integrity of } \\
\text { marine substrates }\end{array}$ & $\begin{array}{l}\text { descriptors } 6 \text { and } 1 \text { regarding } \\
\text { "biodiversity and integrity of the } \\
\text { marine substrates" and descriptor } 4 \\
\text { "webs" }\end{array}$ & \begin{tabular}{lcc} 
Convention & on & \multicolumn{2}{c}{ biodiversity, } \\
European & Strategy & on \\
Biodiversity, & French Strategy & on \\
Biodiversity & &
\end{tabular} \\
\hline $\begin{array}{l}\text { Introduction of energy into the } \\
\text { environment and changes in } \\
\text { water regime }\end{array}$ & $\begin{array}{l}\text { descriptors 11 “energy" } \\
\text { "hydrography" }\end{array}$ & $\begin{array}{l}\text { Environmental } \\
\text { Assessment Directive }\end{array}$ \\
\hline
\end{tabular}


Table 3: Organisations contacted

\begin{tabular}{|c|c|c|c|}
\hline Problem area & Type of organisation contacted & $\begin{array}{l}\text { Number of } \\
\text { organisations } \\
\text { contacted }\end{array}$ & $\begin{array}{l}\text { Response } \\
\text { rate }\end{array}$ \\
\hline Marine litter & $\begin{array}{l}\text { Ministry of the environment, research organisations, } \\
\text { Navy, naval prefecture, regional centres of } \\
\text { surveillance and rescue, environmental NGOs, } \\
\text { maritime ports, environmental consultancy firms, } \\
\text { shellfish and fisheries associations, turtle care centres }\end{array}$ & 15 & $67 \%$ \\
\hline Chemical compounds & $\begin{array}{l}\text { Ministry of the environment, research organisations, } \\
\text { Centre for marine and fluvial technical studies, } \\
\text { maritime ports, French public body in charge of } \\
\text { water management, environmental consultancy firm }\end{array}$ & 25 & $85 \%$ \\
\hline Microbial pathogens & $\begin{array}{l}\text { Ministry of health, Sanitary Surveillance Institute, } \\
\text { Ministry of the environment, Ministry of agriculture } \\
\text { and fisheries, research organisations, NGO, French } \\
\text { public body in charge of water management }\end{array}$ & 7 & $100 \%$ \\
\hline $\begin{array}{l}\text { Oil spills and illegal } \\
\text { discharges of oil }\end{array}$ & $\begin{array}{l}\text { Ministry of the environment, research organisations, } \\
\text { Navy, environmental NGOs, Centre for marine and } \\
\text { fluvial technical studies, maritime ports, naval } \\
\text { prefecture, local authorities, regional fisheries } \\
\text { committees, professional organisation of the French } \\
\text { companies of transport and maritime services, } \\
\text { regional centres of surveillance and rescue, Naval } \\
\text { Hydrographic and Oceanographic Service, } \\
\text { International Oil Pollution Compensation Funds, } \\
\text { regional tourism committee, environmental } \\
\text { consultancy firms, national shellfish committees }\end{array}$ & 25 & $65 \%$ \\
\hline Eutrophication & $\begin{array}{l}\text { Research organisations, French public body in charge } \\
\text { of water management, national and regional } \\
\text { administration, decentralised services of the } \\
\text { agriculture Ministry, decentralised services of the } \\
\text { health Ministry, shellfish committees, tourism } \\
\text { organisations, maritime port, NGOs, organisations } \\
\text { concerned with seaweed management }\end{array}$ & 50 & $60 \%$ \\
\hline $\begin{array}{l}\text { Non-native invasive } \\
\text { species }\end{array}$ & $\begin{array}{l}\text { Ministry of the environment, regional and local } \\
\text { authorities, research organisations, French public } \\
\text { body in charge of water management, regional } \\
\text { shellfish committees, diving clubs, marine protected } \\
\text { areas, NGOs, French Marine Protected Areas Agency }\end{array}$ & 25 & $45 \%$ \\
\hline $\begin{array}{l}\text { Biological degradation } \\
\text { of natural resources } \\
\text { exploited: aquaculture }\end{array}$ & $\begin{array}{l}\text { Ministry of agriculture and fisheries, national and } \\
\text { regional shellfish committees, shellfish technical } \\
\text { centres, research organisations }\end{array}$ & 15 & $100 \%$ \\
\hline $\begin{array}{l}\text { Biological degradation } \\
\text { of natural resources } \\
\text { exploited: fisheries }\end{array}$ & $\begin{array}{l}\text { Ministry of agriculture and fisheries, research } \\
\text { institute, national and regional fisheries committees, } \\
\text { national NGOs }\end{array}$ & 7 & $50 \%$ \\
\hline $\begin{array}{l}\text { Loss of biodiversity, } \\
\text { trophic changes, loss of } \\
\text { integrity of marine } \\
\text { substrates }\end{array}$ & $\begin{array}{l}\text { Ministry of the environment, public organisations in } \\
\text { charge of environment protection, marine protected } \\
\text { areas, environmental consultancy firms, research } \\
\text { institutes, Centre for marine and fluvial technical } \\
\text { studies, operator of the French electricity } \\
\text { transmission system, French committee of granulate } \\
\text { producers, fisheries observers, national and local } \\
\text { NGOs, environment observatories, maritime ports }\end{array}$ & 130 & $80 \%$ \\
\hline Introduction of energy & $\begin{array}{l}\text { French electricity supplier, research organisations, } \\
\text { regional administration, Naval Hydrographic and } \\
\text { Oceanographic Service }\end{array}$ & 5 & $80 \%$ \\
\hline
\end{tabular}


Table 4: Detailed environmental measures whose costs have been estimated in this paper (in grey when the information is missing; when the data collected are incomplete, this is noted in parentheses)

\begin{tabular}{|c|c|c|c|}
\hline Problem area & $\begin{array}{l}\text { Costs of monitoring and } \\
\text { information }\end{array}$ & $\begin{array}{l}\text { Costs of } \quad \begin{array}{c}\text { preventing } \\
\text { environmental degradation }\end{array}\end{array}$ & $\begin{array}{l}\text { Costs of environmental } \\
\text { restoration } \\
\text { remediation }\end{array}$ \\
\hline \multirow[t]{5}{*}{ Marine litter } & $\begin{array}{l}\text { Participation in international } \\
\text { convention }\end{array}$ & $\begin{array}{l}\text { Marine programmes of litter } \\
\text { reduction of the Ministry of the } \\
\text { environment }\end{array}$ & $\begin{array}{l}\text { Collection of litter on } \\
\text { beaches (incomplete data) }\end{array}$ \\
\hline & Research programmes & Awareness-raising campaign & $\begin{array}{l}\text { Collection of litter around } \\
\text { nuclear power plants } \\
\text { (incomplete data) }\end{array}$ \\
\hline & $\begin{array}{l}\text { Ministry of the environment } \\
\text { (Marine programme) }\end{array}$ & $\begin{array}{lll}\text { Certification } & \text { of } & \text { litter } \\
\text { management } & \text { in } & \text { ports } \\
\text { (incomplete data) } & & \\
\end{array}$ & $\begin{array}{l}\text { Collection of litter on the } \\
\text { water surface }\end{array}$ \\
\hline & \multirow{2}{*}{$\begin{array}{lr}\text { Information } & \text { from } \\
\text { Environmental NGOs } & \text { about } \\
\text { litter issues } & \end{array}$} & \multirow[t]{2}{*}{$\begin{array}{l}\text { Improvement of litter } \\
\text { management on beaches }\end{array}$} & $\begin{array}{l}\text { Collection of litter on the } \\
\text { seabed }\end{array}$ \\
\hline & & & Collection of litter in ports \\
\hline \multirow[t]{6}{*}{$\begin{array}{l}\text { Chemical } \\
\text { compounds }\end{array}$} & $\begin{array}{l}\text { Monitoring of pollution on } \\
\text { the coast and in ports }\end{array}$ & Industrial sewage treatment $^{\top}$ & \multirow[t]{6}{*}{ None } \\
\hline & $\begin{array}{l}\text { Monitoring of dragged } \\
\text { sediments (incomplete data) }\end{array}$ & $\begin{array}{l}\text { Collection and treatment of } \\
\text { storm water }\end{array}$ & \\
\hline & $\begin{array}{l}\text { Implementation of REACH } \\
\text { Directive }\end{array}$ & Management of sewage sludge & \\
\hline & $\begin{array}{l}\text { Water Framework Directive } \\
\text { coordination for marine } \\
\text { water }\end{array}$ & \multirow[t]{3}{*}{$\begin{array}{l}\text { Action in the agricultural } \\
\text { domain to reduce the use of } \\
\text { phytosanitary products }\end{array}$} & \\
\hline & $\begin{array}{l}\text { Monitoring of sewage } \\
\text { sludge }\end{array}$ & & \\
\hline & Research programmes & & \\
\hline \multirow[t]{3}{*}{$\begin{array}{l}\text { Microbial } \\
\text { pathogens }\end{array}$} & $\begin{array}{l}\text { Monitoring of pollution on } \\
\text { the coast and in bathing } \\
\text { waters }\end{array}$ & $\begin{array}{l}\text { Domestic sewage } \\
\text { treatment (bacteria) }\end{array}$ & \multirow[t]{3}{*}{$\begin{array}{l}\text { Purification of shellfish } \\
\text { located in a B classified } \\
\text { zone }\end{array}$} \\
\hline & \multirow[t]{2}{*}{$\begin{array}{l}\text { Research on microbial } \\
\text { pathogens }\end{array}$} & $\begin{array}{l}\text { Collection and treatment of } \\
\text { storm water }\end{array}$ & \\
\hline & & $\begin{array}{l}\text { Measures linked to use of } \\
\text { fertiliser in agriculture }\end{array}$ & \\
\hline \multirow[t]{3}{*}{$\begin{array}{l}\text { Oil spills and } \\
\text { illegal } \\
\text { discharges of oil }\end{array}$} & $\begin{array}{l}\text { Research and data collection } \\
\text { programmes (incomplete } \\
\text { data) }\end{array}$ & $\begin{array}{l}\text { Litter collection in ports } \\
\text { (incomplete data) }\end{array}$ & $\begin{array}{l}\text { Mitigation costs of oil spill } \\
\text { impacts }\end{array}$ \\
\hline & \multirow[t]{2}{*}{$\begin{array}{l}\text { Functioning of } \text { monitoring } \\
\text { and rescue } \\
\text { (incomplete data) }\end{array}$} & $\begin{array}{l}\text { Marine pollution prevention } \\
\text { system (POLMAR) (incomplete } \\
\text { data) }\end{array}$ & \multirow[t]{2}{*}{$\begin{array}{l}\text { Valuation of voluntary } \\
\text { work to mitigate oil spill } \\
\text { impacts }\end{array}$} \\
\hline & & $\begin{array}{l}\text { Functioning of a centre } \\
\text { dedicated to prevention and } \\
\text { reduction of marine pollution } \\
(\mathrm{CEDRE})\end{array}$ & \\
\hline \multirow[t]{2}{*}{ Eutrophication } & Coastal monitoring & $\begin{array}{l}\text { Management of } \begin{array}{l}\text { watersheds, } \\
\text { water agencies } \\
\text { (incomplete }\end{array} \\
\end{array}$ & Collection of green algae \\
\hline & Research programmes & $\begin{array}{l}\text { Information on the national } \\
\text { programme }\end{array}$ & Treatment of green algae \\
\hline
\end{tabular}

\footnotetext{
${ }^{1}$ Investment costs of industrial sewage plants over the whole of France (this corresponds to the zone of sensitivity to chemical contamination as identified by experts)

${ }^{2}$ Investment and functioning costs of sewage plants in a $5 \mathrm{~km}$ coastal strip (this corresponds to the zone of sensitivity to microbial contamination as identified by experts)
} 


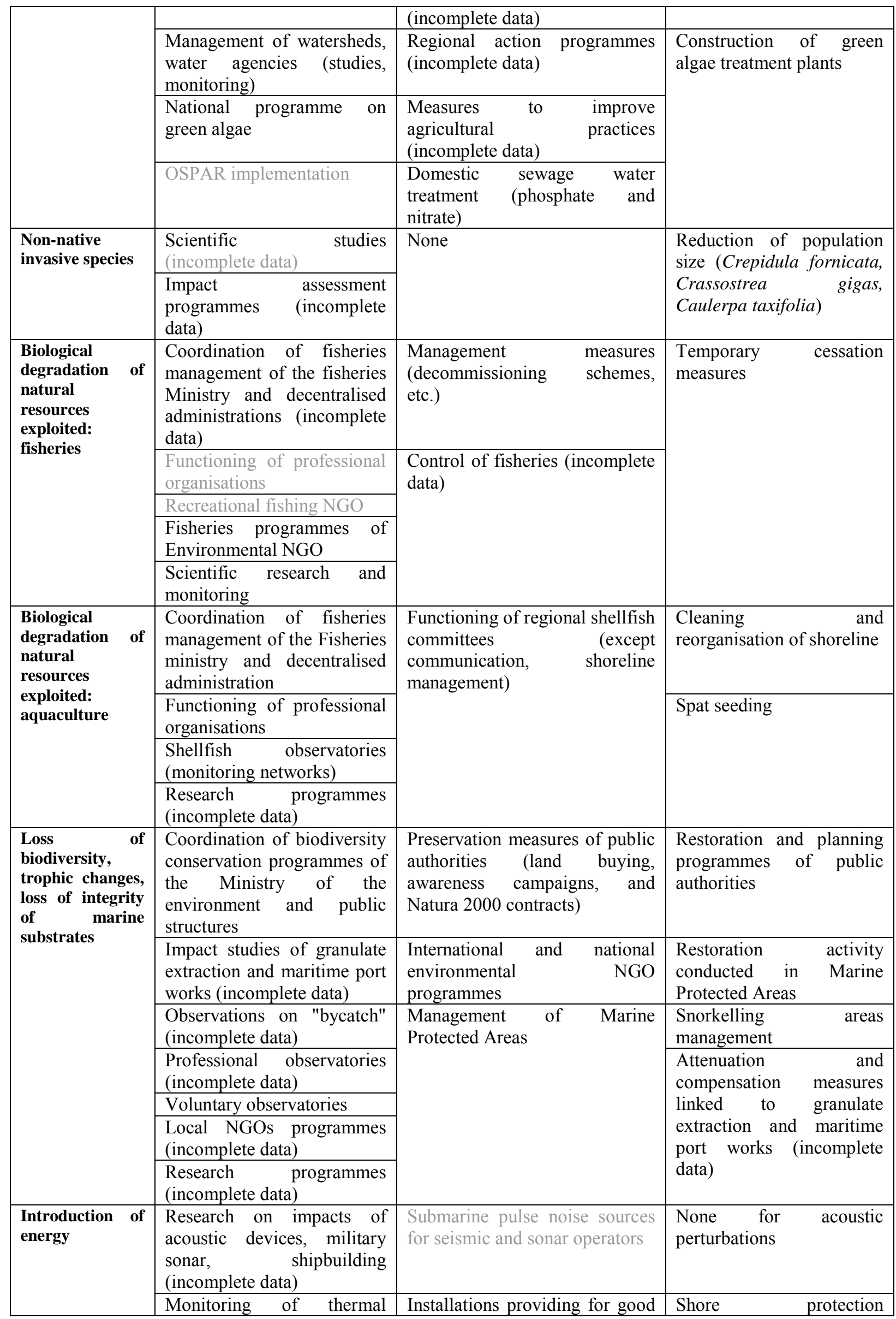




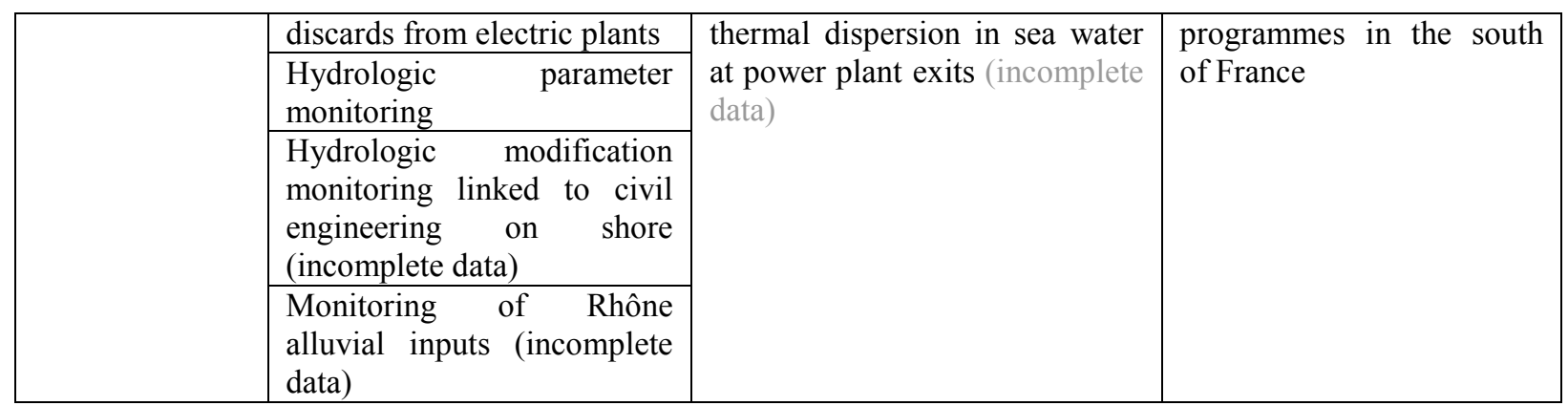


Table 5: Annual costs required to maintain current level of ecological status, detailed by problem areas and types of cost (in millions of Euros; "na"

when the data is not available)

\begin{tabular}{|c|c|c|c|c|c|c|c|c|c|c|c|c|c|c|c|c|c|c|c|}
\hline \begin{tabular}{|l|}
$\begin{array}{r}\text { Problem } \\
\text { areas } \\
\\
\text { Cost } \\
\text { types }\end{array}$ \\
\end{tabular} & & $\begin{array}{c}\text { Loss of } \\
\text { biodiversity }\end{array}$ & $\%$ & $\begin{array}{c}\text { Chemical } \\
\text { compounds }\end{array}$ & $\%$ & $\begin{array}{c}\text { Microbial } \\
\text { pathogens }\end{array}$ & $\%$ & $\begin{array}{c}\text { Decrease } \\
\text { in fish } \\
\text { stocks }\end{array}$ & $\%$ & \begin{tabular}{|} 
Biological \\
degradation \\
of natural \\
resources \\
exploited: \\
aquaculture
\end{tabular} & $\%$ & Eutrophication & $\%$ & $\begin{array}{c}\text { Oil spills } \\
\text { and illegal } \\
\text { discharges } \\
\text { of oil }\end{array}$ & $\%$ & $\begin{array}{l}\text { Introduction } \\
\text { of energy }\end{array}$ & $\%$ & Total & $\%$ \\
\hline \multirow{4}{*}{$\begin{array}{c}\text { Costs of } \\
\text { monitoring } \\
\text { and } \\
\text { information }\end{array}$} & $\begin{array}{l}\text { Organisation in charge of } \\
\text { coordination }\end{array}$ & $8.914 €$ & $18 \%$ & $0.665 €$ & $1 \%$ & na & - & $13.000 €$ & $26 \%$ & $7.300 €$ & $15 \%$ & na & - & $19.334 €$ & $40 \%$ & na & - & $49.213 €$ & $100 \%$ \\
\hline & \begin{tabular}{|l} 
Observation, monitoring, studies, \\
expert analysis, impact assessment
\end{tabular} & 23.071 & $18 \%$ & $65.166 €$ & $51 \%$ & $5.828 €$ & $5 \%$ & $23.700 €$ & $18 \%$ & $5.216 €$ & $5 \%$ & $2.909 €$ & $3 \%$ & na & - & $2.600 €$ & $2 \%$ & $128.489 €$ & $100 \%$ \\
\hline & Research & 45.525 & $84 \%$ & $0.117 €$ & $0 \%$ & $2.302 €$ & $5 \%$ & na & - & $3.455 €$ & $6 \%$ & $0.189 €$ & $0 \%$ & $1.801 €$ & $4 \%$ & $0.527 €$ & $1 \%$ & $53.915 €$ & $100 \%$ \\
\hline & SUB-TOTAL & $77.510 €$ & & $65.948 €$ & & $8.129 €$ & & $36.700 €$ & & $15.971 €$ & & $3.098 €$ & & $21.135 €$ & & $3.127 €$ & & $231.618 €$ & \\
\hline$\%$ & & $52 \%$ & & $19 \%$ & & $1 \%$ & & $28 \%$ & & $53 \%$ & & $7 \%$ & & $45 \%$ & & $6 \%$ & & $11 \%$ & \\
\hline $\begin{array}{c}\text { Costs of } \\
\text { preventing } \\
\text { environmental } \\
\text { degradation }\end{array}$ & $\begin{array}{l}\text { Measures for sustainable } \\
\text { management (MPA, contracts, } \\
\text { pollution treatment), control and } \\
\text { enforcement } \\
\text { SUB-TOTAL }\end{array}$ & $41.669 €$ & $2 \%$ & $281.770 €$ & $16 \%$ & $\begin{array}{c}1,232.666 \\
€\end{array}$ & $71 \%$ & $90.200 €$ & $6 \%$ & $11.506 €$ & $1 \%$ & $35.507 €$ & $2 \%$ & $7.602 €$ & $0 \%$ & $38.600 €$ & $2 \%$ & $\begin{array}{c}1,739.521 \\
€\end{array}$ & $100 \%$ \\
\hline$\%$ & & $28 \%$ & & $81 \%$ & & $98 \%$ & & $67 \%$ & & $38 \%$ & & $74 \%$ & & $16 \%$ & & $73 \%$ & & $85 \%$ & \\
\hline \multirow{3}{*}{$\begin{array}{c}\text { Costs of } \\
\text { environmental } \\
\text { restoration } \\
\text { and } \\
\text { remediation }\end{array}$} & $\begin{array}{l}\text { Compensatory measures (legal } \\
\text { obligation) }\end{array}$ & $11.181 €$ & $46 \%$ & $0 €$ & $0 \%$ & $6.260 €$ & $26 \%$ & $6.800 €$ & $28 \%$ & $0 €$ & $0 \%$ & $8.840 €$ & $0 \%$ & $18.571 €$ & & $11.000 €$ & & $24.242 €$ & $100 \%$ \\
\hline & $\begin{array}{l}\text { Restoration and compensation } \\
\text { (voluntary) }\end{array}$ & $18.131 €$ & $88 \%$ & $0 €$ & $0 \%$ & $0 €$ & $0 \%$ & na & - & $2.574 €$ & $12 \%$ & $0 €$ & $0 \%$ & $0 €$ & $0 \%$ & $0 €$ & $0 \%$ & $20.705 €$ & $100 \%$ \\
\hline & SUB-TOTAL & $29.312 €$ & & $0 €$ & & $6.260 €$ & & $6.800 €$ & & $2.574 €$ & & $8.840 €$ & & $18.571 €$ & & $11.000 €$ & & $83.358 €$ & \\
\hline$\%$ & & $20 \%$ & & $0 \%$ & & $1 \%$ & & $5 \%$ & & $9 \%$ & & $19 \%$ & & $39 \%$ & & $21 \%$ & & $4 \%$ & \\
\hline TOTAL & & $148.491 €$ & $7 \%$ & $347.718 €$ & $17 \%$ & $\begin{array}{c}1,247.056 \\
€\end{array}$ & $61 \%$ & $\begin{array}{c}133.700 \\
€\end{array}$ & $7 \%$ & $30.051 €$ & $1 \%$ & $47.445 €$ & $2 \%$ & $47.308 €$ & $2 \%$ & $52.727 €$ & $3 \%$ & $\begin{array}{c}2,054.496 \\
€\end{array}$ & $100 \%$ \\
\hline$\%$ & & $100 \%$ & & $100 \%$ & & $100 \%$ & & $100 \%$ & & $100 \%$ & & $100 \%$ & & $100 \%$ & & $100 \%$ & & & \\
\hline
\end{tabular}




\section{Annex 1: The Marine Strategy Framework Directive}

The environmental component of the European integrated marine approach is represented by the Marine Strategy Framework Directive (2008/56/EC) (MSFD), which establishes a framework for community action in the area of marine environmental policy. The Directive provides a legislative framework for the ecosystem approach to the management of those human activities which impact the marine environment, and integrates the concepts of environmental protection and sustainable use. This involves several steps:

- the initial assessment of the current environmental status of national marine waters and the environmental impact and socio-economic analysis of human activities in these waters (by 15 July 2012)

- the definition of a Good Environmental State (GES) for national marine waters (by 15 July 2012)

- the establishment of environmental targets and associated indicators for achieving a GES by 2020 (by 15 July 2012)

- the establishment of a monitoring programme for the ongoing assessment and regular update of targets (by 15 July 2014)

- the development of a programme of measures designed to achieve or maintain a GES by 2020 (by 2015)

- the review and preparation of the second cycle (2018-2021).

Member States are to make an initial assessment of their marine waters in each marine region or sub-region, taking account of existing data (where available). This will comprise:

- an analysis of the essential features and characteristics, and current environmental status, of those waters

- an analysis of the predominant pressures and impacts, including human activity, on the environmental status of those waters

- an economic and social analysis of the use of those waters and of the costs of degradation of the marine environment. 